\title{
Do Blood Group Antigens and the Red Cell Membrane Influence Human Immunodeficiency Virus Infection?
}

\author{
Glenda M. Davison ${ }^{1,2, *(\mathbb{D})}$, Heather L. Hendrickse ${ }^{1}(\mathbb{D})$ and Tandi E. Matsha ${ }^{1}$ \\ 1 SAMRC/CPUT/Cardiometabolic Health Research Unit, Department of Biomedical Sciences, Faculty of \\ Health and Wellness Sciences, Cape Peninsula University of Technology, P.O. Box 1906, Bellville 7530, \\ South Africa; hendricksehl@cput.ac.za (H.L.H.); matshat@cput.ac.za (T.E.M.) \\ 2 Division of Haematology, Faculty of Health Science, University of Cape Town, Cape Town 7925, South Africa \\ * Correspondence: davisong@cput.ac.za; Tel.: +27-21-959-6562; Fax: +27-21-959-6760
}

Received: 26 January 2020; Accepted: 26 March 2020; Published: 31 March 2020

\begin{abstract}
The expression of blood group antigens varies across human populations and geographical regions due to natural selection and the influence of environment factors and disease. The red cell membrane is host to numerous surface antigens which are able to influence susceptibility to disease, by acting as receptors for pathogens, or by influencing the immune response. Investigations have shown that Human Immunodeficiency Virus (HIV) can bind and gain entry into erythrocytes, and therefore it is hypothesized that blood groups could play a role in this process. The ABO blood group has been well studied. However, its role in HIV susceptibility remains controversial, while other blood group antigens, and the secretor status of individuals, have been implicated. The Duffy antigen is a chemokine receptor that is important in the inflammatory response. Those who lack this antigen, and type as Duffy null, could therefore be susceptible to HIV infection, especially if associated with neutropenia. Other antigens including those in the Rh, Lutheran and OK blood group systems have all been shown to interact with HIV. More recently, experiments show that cells which overexpress the $\mathrm{P}^{\mathrm{k}}$ antigen appear to be protected against infection. These reports all demonstrate that red cell antigens interact and influence HIV infection. However, as the red cell membrane is complex and the pathogenesis of HIV multi-factorial, the role of blood group antigens cannot be studied in isolation.
\end{abstract}

Keywords: red cells; blood group antigens; Human Immunodeficiency Virus

\section{Introduction}

It has been estimated that 37.9 million people carry Human Immunodeficiency Virus (HIV) and that Sub-Saharan Africa has the highest burden of infection [1]. Consequently, research on HIV has been extensive, and it has been well documented that the virus binds to the CD4 antigen and chemokine receptors (CXR4 and CCR5) in order to gain entry into cells and replicate [2]. Evidence has, however, emerged that the virus is also able to attach to CD4-negative cells such as erythrocytes. This was initially demonstrated in the presence of complement, and it was proposed, at that time, that the complement receptor $1(\mathrm{CR} 1)$ is the most likely mechanism of entry [3]. Others have gone on to reveal that in the absence of antibodies and complement, cell-free HIV was still capable of binding to red cells and, consequently, it was concluded that red cells, like dendritic cells, could act as a viral reservoir prior to the invasion of CD4+ cells [4]. Recently, further research has established that circulating immature CD71+ erythrocytes in HIV + individuals are host to both intracellular and surface HIV particles, which significantly increases the movement, infectivity and replication of the virus [5]. These reports have all raised questions around the exact mechanism of HIV attachment and whether blood group antigens influence susceptibility. 
The red cell membrane is host to approximately four hundred different surface antigens which have been grouped into thirty-six blood group systems [6,7]. The majority of these have been cloned and sequenced and have diverse functions, including structural, cellular transport and immune activation (Table 1) [6,7]. The distribution of blood groups varies between populations and geographical regions, and it has generally been accepted that this is due to natural selection, environmental factors and disease [8-10]. Blood group antigens are not only confined to red cells but can be found on other cells and tissue types, including epithelium and body fluids. This is dependent on the secretor status of individuals and the expression of the Fucosyltransferase 2 (FUT2) enzyme. Due to the diverse cellular and tissue expression of $\mathrm{ABO}$ antigens, they have been associated with many conditions including cardiovascular disease, venous thrombosis and malignancy [10-13].

Table 1. Blood group systems recognized by the International Society of Blood Transfusion.

\begin{tabular}{|c|c|c|c|c|}
\hline System & Chromosome & Gene & Type & Function \\
\hline $\mathrm{ABO}$ & $9 q 34.2$ & $A B O$ & Carbohydrate & Glycosyltransferase \\
\hline MNS & $4 \mathrm{q} 31.21$ & $\begin{array}{l}\text { GYPA } \\
\text { GYPB }\end{array}$ & Single-pass protein & $\begin{array}{l}\text { Single-pass protein, band } 3 \text { ankyrin } \\
\text { complex, red cell zeta potential }\end{array}$ \\
\hline PIPK & $22 \mathrm{q} 13.2$ & A4GALT1 & Carbohydrate & $\alpha 1,4$ Galactosyltransferase \\
\hline $\mathrm{Rh}$ & $1 \mathrm{p} 36.11$ & $\begin{array}{l}\text { RHD } \\
\text { RHCE }\end{array}$ & Multi-pass protein & $\begin{array}{l}\text { Ammonium transport, band } 3 \\
\text { metabolism }\end{array}$ \\
\hline Lutheran & $19 q 13.32$ & $L U$ & Single-pass protein & Laminin receptor \\
\hline Kell & $7 q 34$ & KEL & Single-pass protein & Endothelin 3-converting enzyme \\
\hline Lewis & 19p13.3 & FUT3 & Carbohydrate & $\alpha \frac{3}{4}$-Fucosyltransferase \\
\hline Duffy & $1 \mathrm{q} 23.2$ & $D A R C$ & Multi-pass protein & Chemokine receptor \\
\hline Kidd & $18 \mathrm{q} 12.3$ & SLC14A1 & Multi-pass protein & Urea transport \\
\hline Diego & $17 q 21.31$ & $S L C 4 A 1$ & Multi-pass protein & $\begin{array}{l}\text { Band 3/anion exchange/cytoskeleton } \\
\text { stability }\end{array}$ \\
\hline Cartwright/Yt & $7 \mathrm{q} 22.1$ & $A C H E$ & GPI-linked protein & Acetylcholinesterase \\
\hline $\mathrm{Xg}$ & Xp22.33 & XG, MIC2 & Single-pass protein & Adhesion molecule \\
\hline Scianna & $1 \mathrm{p} 34.2$ & ERMAP & Single-pass protein & Unknown \\
\hline Dombrock & $12 \mathrm{p} 12.3$ & ART4 & GPI-linked protein & ADP-ribosyltransferase \\
\hline Colton & $7 \mathrm{p} 14.3$ & $A Q P 1$ & Multi-pass protein & Water transport/band 3 metabolism \\
\hline Landsteiner-Wiener & 19p13.2 & ICAM4 & Single-pass protein & Adhesion molecule \\
\hline Chido/Rodgers & $6 \mathrm{p} 21.3$ & $C 4 A, C 4 B$ & $\begin{array}{l}\text { Absorbed from } \\
\text { plasma }\end{array}$ & Complement, C4 \\
\hline $\mathrm{H}(\mathrm{SE})$ & $19 q 13.33$ & $\begin{array}{l}\text { FUT1 } \\
\text { FUT2 }\end{array}$ & Carbohydrate & $\begin{array}{c}\alpha 1,2 \text {-Fucosyltransferase, type } 2 \mathrm{H} \text { antigen } \\
\alpha 1,2 \text {-Fucosyltransferase, type } 1,3 \text { and } 4, \\
\text { secretor (ABH) }\end{array}$ \\
\hline $\mathrm{Kx}$ & Xp21.1 & $X K$ & Multi-pass protein & Unknown \\
\hline Gerbich & $2 q 14.3$ & GYPC & Single-pass protein & $\begin{array}{l}\text { Glycophorins C and D, membrane } \\
\text { stability }\end{array}$ \\
\hline Cromer & $1 \mathrm{q} 32.2$ & CD55 & GPI-linked protein & Complement regulation \\
\hline Knops & $1 \mathrm{q} 32.2$ & CR1 & Single-pass protein & Complement regulation \\
\hline Indian & $11 \mathrm{p} 13$ & $C D 44$ & Single-pass protein & Cell adhesion \\
\hline Ok & 19p13.3 & $B S G$ & Single-pass protein & $\begin{array}{l}\text { Cell trafficking, cytophillin receptor, } \\
\text { adhesion and signaling }\end{array}$ \\
\hline Raph & $11 \mathrm{p} 15.5$ & CD151 & Multi-pass protein & Cell adhesion \\
\hline John Milton Hagan & $15 q 21.1$ & SEMA7A & GPI-linked protein & $\begin{array}{l}\text { T-cell-mediated inflammation, integrin } \\
\text { receptor }\end{array}$ \\
\hline I & $6 \mathrm{p} 24.2$ & GCNT2 & Carbohydrate & $\beta 1,6-\mathrm{N}$-acetylglucosaminyltransferase \\
\hline
\end{tabular}


Table 1. Cont.

\begin{tabular}{|c|c|c|c|c|}
\hline System & Chromosome & Gene & Type & Function \\
\hline Globoside & $3 q 26.1$ & B3GALNT1 & Carbohydrate & $\beta 1,6-\mathrm{N}$-acetylgalactosaminyltransferase \\
\hline Gill & $9 p 13.3$ & $A Q P 3$ & Multi-pass protein & Water, glycerol, peroxide transport \\
\hline $\begin{array}{l}\text { Rh-Associated } \\
\text { glycoprotein }\end{array}$ & $6 \mathrm{p} 21$ & RHAG & Multi-pass protein & $\begin{array}{c}\text { Ammonium transport-associated RhD } \\
\text { and RhCE }\end{array}$ \\
\hline FORS & $9 q 34.13$ & GBGT1 & Carbohydrate & $\alpha 1,3-\mathrm{N}$-acetylgalactosaminyltransferase \\
\hline $\mathrm{JR}$ & $4 \mathrm{p} 22$ & $A B C G 2$ & Multi-pass protein & ATP-dependent transport \\
\hline Lan & $2 q 36$ & $A B C G 6$ & Multi-pass protein & Porphyrin and heme transport \\
\hline $\begin{array}{l}\text { Vel } \\
\text { CD59 } \\
\text { Augustine } \\
\text { KANNO } \\
\text { Sid }\end{array}$ & $\begin{array}{l}1 \mathrm{p} 36.32 \\
11 \mathrm{p} 13 \\
6 \mathrm{p} 21.1 \\
20 \mathrm{p} 13 \\
17 \mathrm{q} 21.32\end{array}$ & $\begin{array}{c}\text { SMIM1 } \\
\text { CD59 } \\
\text { SLC29A1 } \\
\text { PRNP } \\
\text { B4GALNT2 }\end{array}$ & $\begin{array}{l}\text { Single-pass protein } \\
\text { GPI-linked protein } \\
\text { Multi-pass protein } \\
\text { Prion protein }\end{array}$ & $\begin{array}{l}\text { Red cell formation regulation } \\
\text { Complement regulation } \\
\text { Protein transporter } \\
\text { Acetylgalactosaminyltransferase }\end{array}$ \\
\hline
\end{tabular}

The presence or absence of red cell antigens has also been implicated in the susceptibility and pathogenesis of bacterial, viral and parasitic infections. These include Vibrio cholera [14], Escherichia coli [15], Helicobacter pylori [16], Norovirus [17], Rotavirus [18], and Human Immunodeficiency Virus (HIV) [6,19]. A well-described example is the Duffy antigen, which has been identified as a receptor for the parasite Plasmodium vivax. In Sub-Saharan Africa, where the majority of the population phenotype as Duffy null (Fy(a-b-)) and do not express this antigen, many individuals are protected against both Plasmodium vivax and Plasmodium knowlesi [20].

These reports all provide evidence that blood group antigens could influence the pathogenesis of infectious disease including HIV. Despite this, the relationship between these red cell surface antigens and HIV still remains complex, controversial and not fully explained.

With this in mind, the main objective of this review was to re-examine the current knowledge on this subject in an attempt to provide further clarity on the association between HIV and red cell antigens.

\section{Human Immunodeficiency Virus}

Human Immunodeficiency Virus (HIV) belongs to the family of Retroviridae and the genus Lentivirus. The structure of both the HIV-1 and HIV-2 strains is similar, and both possess a lipid-protein membrane. Embedded in the membrane is glycoprotein gp41, which is attached to gp120. Both surface proteins are encoded by the $e n v$ gene and are vital in attaching the virus to the host cell by binding to cell surface receptors. Beneath the surface membrane is $\mathrm{p} 17$, a matrix protein that is encoded by the gag gene. This gene also encodes the core proteins $\mathrm{p} 24$ and p6 and the nucleocapsid protein p7 which is bound to viral RNA [21,22].

The virus contains two strands of RNA, together with the enzymes, protease, integrase, and reverse transcriptase-all of which are essential in the replication process, and are encoded by the pol gene. Other proteins such as Tat, promote transcription, while Rev is responsible for the transport of messenger RNA from the nucleus to the cytoplasm. Vpr, another protein, ensures that the reverse transcribed DNA is able to access the nucleus of non-dividing cells, while signal transduction and the down-regulation of the CD4 antigen, in order to allow the budding process to take place, is facilitated by the viral protein known as Nef [21,22].

\section{HIV Replication}

Replication is initiated upon the attachment of the virus to the host cell. The proteins gp120 and gp41 are essential for this to occur and it begins with gp120 binding to the CD4 molecule, which is expressed on T helper cells, macrophages, eosinophils and dendritic cells [23]. Once this has taken place, a structural change occurs which allows gp120 to bind the chemokine receptors CXR4 and CCR5, 
on the cell surface. The natural ligands of CCR5, RANTES and MIP-1- $\alpha$ and $\beta$, are potentially able to suppress HIV infection and have been shown to compete with HIV for binding [24].

After attachment, gp41 penetrates the host cell membrane and forms a loop structure that allows the virus to enter the cell. The viral RNA is released into the cytoplasm and is converted by reverse transcription into pro-viral DNA. After double-stranded DNA is formed, it is integrated into the genome of the host cell by the enzyme Integrase [25].

Recent investigations, utilizing multi-color single-molecule localization microscopy (SMLM) and two-color photoactivated localization microscopy (PALM), have demonstrated that gp41 is also able to interact with the T-cell receptor (TCR) on CD4+ T-cells. This interaction was shown to lead to early activation of the cell, with phosphorylation of the TCR, upregulation of CD69 and cell death after approximately $24 \mathrm{~h} \mathrm{[26].} \mathrm{This} \mathrm{information} \mathrm{is} \mathrm{important} \mathrm{as} \mathrm{once} \mathrm{the} \mathrm{activation} \mathrm{of} \mathrm{the} \mathrm{target} \mathrm{cell} \mathrm{occurs,}$ the pro-viral DNA is transcribed into messenger RNA and the synthesis of new viral proteins begins. The new viruses move toward the cell surface and are released into the circulation by a process called "budding". During this process, HIV incorporates many of the host cell proteins, including ABO carbohydrate molecules, which become part of the surface membrane [27].

\section{The ABO Blood Group System}

The ABO blood group system has evolved over millions of years and at least two theories on how this occurred have been proposed. One hypothesis is that group $\mathrm{O}$ was the original blood group and that groups A and B were the results of mutations that occurred due to population migration and environmental factors. This has been supported by the high prevalence of group $\mathrm{O}$ amongst the earliest human populations [12,28-30]. In contrast, others suggest that group $\mathrm{O}$, which results from the inactivation of the A1 glycosyltransferase gene, evolved from a common group $\mathrm{AB}$ due to the selective advantage and natural resistance of Group $\mathrm{O}$ individuals to the malaria parasite. This has been supported by observations that individuals with blood type $\mathrm{O}$ are protected against severe malaria due to decreased red cell rosetting and adherence [20,31,32]. This evolutionary history is relevant as it illustrates the relationship of blood groups with the environment, and how the expression of blood group antigens has evolved in response to diseases.

The $A B O$ gene does not code directly for $\mathrm{ABO}$ antigens but for specific enzymes called glycosyltransferases, which transfer $\mathrm{N}$-galactosamine (group A) or D-galactose (group $\mathrm{B}$ ) to the $\mathrm{H}$ antigen to form the $\mathrm{A}$ and $\mathrm{B}$ blood group antigens. This does not occur in group $\mathrm{O}$ individuals and their red cells express the $\mathrm{H}$ antigen [9]. The resulting A, B and $\mathrm{H}$ antigens contain a lipophilic section which is attached to the red cell membrane and a carbohydrate chain which protrudes above the cell surface [6]. The exact function of the $\mathrm{ABO}$ system remains unclear. However, in red cells, they appear to play a role in the formation of the glycocalyx [8]. During early life, after exposure to the environment, the immune system forms naturally occurring antibodies against those $\mathrm{A}$ and $\mathrm{B}$ antigens which are missing, while both anti-A and anti-B antibodies are present in Group O. These are powerful IgM antibodies that cause blood transfusion reactions if incompatible blood is transfused [6,9,31,32].

The influence of the $\mathrm{ABO}$ blood group system on the pathogenesis of disease has been described by many researchers and its role in the susceptibility or protection against HIV has been widely debated [6]. It has been suggested that polymorphic blood group antigens expressed on the surfaces of epithelia, red blood cells, platelets, and granulocytes are utilized as attachment receptors by HIV and that anti-A and/or anti-B naturally occurring antibodies could confer protection by neutralizing the virus [33]. Evidence for these hypotheses has been provided by studies which have shown that mononuclear cells and lymphocytes can adsorb ABO antigens from the surrounding plasma and that, during the "budding process", HIV can incorporate these antigens onto the viral surface, as they have been found bound to gp120 [27]. Further in vitro investigations have gone on to demonstrate that the viral bound $\mathrm{ABO}$ antigens result in HIV becoming sensitized to naturally occurring, complement-fixing IgM antibodies which could neutralize the virus [27,34]. These experiments have led to the hypothesis that naturally occurring $\mathrm{ABO}$ antibodies could be part of the innate immune response and may provide 
protection when the virus is transmitted between individuals who have different blood groups [35]. Despite these reports, the role of the ABO system in the pathogenesis and susceptibility to HIV infection has remained unclear, initiating further population-based studies.

However, investigations examining the relationship between $\mathrm{ABO}$ antigens and HIV infection still remain controversial. Early studies in India reported a high incidence of HIV positivity among Group O individuals, but these results could not produce statistically reliable conclusions [36] and have been challenged by others who have demonstrated significantly decreased HIV positivity among Group O individuals [37]. Others have reported higher HIV-2 infection rates amongst those who are $\mathrm{AB}$ positive [38] and in Brazil, a higher frequency of HIV was observed amongst those who were group $B$ [39]. Furthermore, a number of studies could not demonstrate any association between $A B O$ antigen expression and HIV infection $[19,40,41]$ and concluded that this blood group system probably does not influence susceptibility. The majority of these reports were superficial and did not include large numbers of participants or account for population and ethnic differences. Therefore, clarity on the $\mathrm{ABO}$ blood group and HIV infection still remains vague and debatable.

Other researchers, realizing that the influence of the $\mathrm{ABO}$ blood group is multi-factorial and probably involves other factors, went on to examine its association with the CD4 count during the course of the disease. This investigation demonstrated that HIV patients with blood groups $\mathrm{A}$ and $\mathrm{AB}$ maintained significantly higher CD4 counts than the other blood groups [42]. These authors again suggested a role for the $\mathrm{ABO}$ antigens in the immune response and proposed that $\mathrm{ABO}$ antigens may be more important in the progression of the disease rather than in initial infection. Although these findings added interesting information, they did not conclusively link HIV to the ABO blood group system, and so it is clear that further research with larger numbers and more rigorous analysis is needed to fully answer the question.

$\mathrm{ABO}$ blood group antigens are also found on the surface of mucosal epithelial tissue and in body fluids including the genital tract. This is dependent on the activity of the enzyme, Fucosyltransferase 2 (FUT2), which is responsible for ABO biosynthesis in body fluids [43]. Approximately $20-30 \%$ of people do not synthesize this enzyme, are unable to express blood group antigens in body fluids and are termed non-secretors. The secretor status of individuals has been shown to influence other viral infections, such as the norovirus, which binds to antigens expressed on mucosal surfaces of the gastrointestinal tract [44-46]. This association of FUT2 and disease has led to the hypothesis that non-secretors could be protected against HIV infection [47].

An early study conducted on 219 heterosexual individuals revealed a significantly higher incidence of secretors among those who had acquired HIV through sexual intercourse compared to those who had acquired it through intravenous drug use. This implied that the expression of ABO antigens on mucosal surfaces could influence infection [48]. This early work has been supported by three independent studies conducted in Senegal, Kenya, and Nigeria. In each of these, it was demonstrated that individuals who were secretors had a higher incidence of HIV positivity and that those who did not have the FUT2 enzyme appeared to have a certain amount of protection. It was hypothesized that this phenomenon could be due to the slower progression of the disease [45,47]. Although these studies are of interest, once again, they are not conclusive and therefore confirmation by larger more comprehensive research is still required.

Despite a number of investigators attempting to study and verify the link between $\mathrm{ABO}$ blood group antigens and HIV infection, the number of authors claiming an association is similar to those who have concluded that there is no relationship. It is therefore clear that more in depth rigorous research, across larger populations and not just small localized groups, is required before this question can be fully answered.

\section{The Duffy Blood Group System}

The Duffy blood group antigen, also known as the Duffy antigen receptor for chemokines (DARC), is a large multi-pass protein that spans the red cell membrane seven times and has a 62 amino acid 
extracellular N-terminal domain [6]. Its expression is controlled by two alleles $\left(F Y^{*} 1\right.$ and $\left.F Y^{*} 2\right)$ which encode the $F Y^{a}$ and $F Y^{b}$ antigens $[7,31]$ and it can be found on the surface of red cells and other tissue such as brain, kidney and endothelium [49].

DARC functions as a chemokine receptor, binds a wide range of inflammatory cytokines including interleukin 8, RANTES and monocyte chemoattractant protein (MCP-1) and is thought to modulate the immune response [50]. The majority of individuals descended from Africa do not express the DARC antigen on their red cells and have the Duffy null phenotype ((Fy(a-b-)) which provides protection to infection by the Plasmodium vivax and Plasmodium knowlesi malaria parasite. The lack of DARC expression in these individuals is due to a polymorphism in the $F Y$ gene promoter region which affects the binding site for the GATA transcription factor in erythrocytes, but not in other cells such as those of the endothelium [51]. As a chemokine receptor, DARC is able to bind HIV-2 but not HIV-1 and may, therefore, influence both initial infection, replication and progression [50,52].

Like the ABO blood group, the relationship between the Duffy antigen and HIV remains controversial. It has, however, been established that Duffy-null individuals have lower levels of inflammatory chemokines such as MCP-1 in their plasma [50]. These cytokines play an important role in the immune response and are able to inhibit HIV infection, and therefore a disruption in their balance could influence susceptibility to the virus. This finding, together with the fact that certain strains of the virus are able to attach to DARC, seemed to suggest that those who are Duffy null could be more susceptible to HIV infection.

A study of African Americans, in which the relationship between DARC expression and HIV was investigated, seemed to support this proposal. The results revealed that those with the Duffy null phenotype were more likely to be infected; however, more importantly, these individuals appeared to have a significantly slower progression [53]. Similar results were reported in 2009 [54] and, although many questions remained unanswered, it appeared that the lack of the Duffy antigen influenced the interaction of the virus with chemokines and that this consequently interfered with the balance and process of inflammation [51].

Benign Ethnic Neutropenia (BEN) is associated with the Duffy null phenotype and, as neutrophils are part of the innate immune system, it has been hypothesized that there could be a relationship between BEN, the Duffy antigen and HIV. A study of 142 high-risk sex workers in South Africa appeared to confirm this, as those who had both the Duffy null phenotype and associated neutropenia had a higher seroconversion rate, which implied that the Duffy null phenotype alone did not increase susceptibility [55]. This report, although providing interesting new knowledge, has not been verified and again, further in depth investigations which explore the mechanisms of this phenomenon are required.

Despite the evidence supporting the relationship between the Duffy null phenotype and HIV, there has been an equal number of studies that have contradicted these findings and have reported no significant association $[19,37,56]$. Two of these were conducted in Sub-Saharan Africa on small numbers of patients using phenotypic assays [19,37], while the third examined the genotype of 454 $\mathrm{HIV}+$ and $425 \mathrm{HIV}$ - African Americans [56]. In all three investigations, the difference between the $\mathrm{HIV}+$ and HIV- groups were insignificant.

These reports all imply that the relationship between the Duffy blood group system and HIV is far more complex than it appears and that more comprehensive investigation and research is required. However, as the Duffy blood antigen plays a significant role in the inflammatory process and functions as a chemokine receptor, the hypothesis that this antigen influences the evolution of HIV infection remains reasonable and therefore more comprehensive investigation is recommended.

\section{The Rh Blood Group}

The Rh blood group system antigens are highly immunogenic and are encoded by the RHD and RHCE genes. A total of 49 antigens have been identified —of which, D (RH1), C (RH2), E (RH3), c (RH4), and e (RH5) are the most common. The Rh antigen is a complex multi-pass protein which transverses 
the cell membrane 12 times. A proportion of the human population lacks the $\mathrm{D}$ antigen, which is a result of a deletion of the RHD gene. The function of the Rh antigens remains vague. However, research has shown that they are associated with the maintenance of red cell integrity and the band 3 protein structure and that they play a role in ammonium transport [8].

Studies examining the Rh blood group system in HIV are scarce and contradictory [36,38]. The most probable reason for this is the low numbers of HIV-positive participants in comparison to controls which has made statistically significant conclusions difficult. However, a study carried out on 346 HIV-negative and 196 HIV-positive Botswanans found that the expression of Rh antigen C (RH2) and E (RH3) was significantly decreased in those who were HIV positive, implying that they could have a protective role. However, in order to further interrogate this result, binary logistic regression analysis was used to analyze the interaction of all significant blood groups. Following this, only the $\mathrm{C}$ antigen maintained its significance, implying that it could have a protective effect [19].

A further investigation on a similar number of participants from South Africa (119 HIV positive vs. 317 HIV negative) examined both Rh antigen expression and genotype. This study did not confirm the findings from Botswana but did report that none of the HIV-positive individuals were RH1 negative or had the genotype $r r$. [37]. This study however, had a significant number of limitations, including the lack of demographic data and the very low number of individuals who had the $r r$ genotype. This made any conclusions on the influence of the Rh antigen unreliable.

Although these two reports from Southern Africa seemed to imply that the Rh blood group system may play a role in the pathogenesis of the virus, both studies were superficial and therefore inconclusive. The relationship of the Rh blood group system with HIV and the mechanism of interaction, if any, still remains purely speculation.

\section{The $P^{k}$ Antigen}

When first described, the P blood group consisted of three antigens (P, P1 and $\mathrm{P}^{\mathrm{k}}$ ) and, although the $\mathrm{P} 1$ antigen is exclusive to red cells, $\mathrm{P}^{\mathrm{k}}$ and $\mathrm{P}$ can be expressed on other cells such as lymphocytes, platelets, and endothelium. Over time, the P blood group has been expanded and is now recognized as three separate blood group systems (PIPK, Globoside and Forssman) with six different antigens [6]. The presence of these antigens in the urinary tract has been strongly associated with E. coli infections [6] and therefore this blood group may be a candidate for investigation in the context of HIV. A study in Botswana demonstrated that red cell-bound P1 antigen was associated with a significantly higher risk of HIV infection [19] and other studies have focused on the $\mathrm{P}^{\mathrm{k}}$ antigen [57].

Glycosphingolipids are able to bind to HIVgp120 and are therefore associated with the binding of viruses to host cells [6,57]. The $\mathrm{P}^{\mathrm{k}}$ antigen is a glycosphingolipid and it has been shown that in Fabrys disease, which has increased amounts of the $P^{k}$ antigen within cells, HIV-1 is inhibited [57]. This has led to investigations that have focused specifically on the $\mathrm{P}^{\mathrm{k}}$ antigen.

Experiments were conducted in which the resistance or susceptibility to HIV infection was compared between peripheral blood mononuclear cells which overexpressed $\mathrm{P}^{\mathrm{k}}$ to those which had no expression. Those which lacked $\mathrm{P}^{\mathrm{k}}$ on their surface had significantly increased susceptibility to $\mathrm{HIV}$, and this finding was confirmed in genetically manipulated CD4+ HeLa cells [10]. These in vitro experiments imply that $\mathrm{P}^{\mathrm{k}}$ could be important in the protection against HIV infection and it is thought that the antigen competes with CCR5 and CXCR4 in binding to HIVgp120. When $P^{k}$ is highly expressed, HIV will preferentially attach to it, preventing fusion and penetration of the cell [10]. The $\mathrm{P}^{\mathrm{k}}$ antigen is a very rare blood group antigen, making large studies difficult. However, these findings could assist in developing therapies for the prevention of infection.

\section{Other Blood Group Antigens}

The Lutheran blood group antigens transverse the red cell membrane once, are members of the immunoglobulin superfamily and function as laminin receptors [58]. In patients with sickle cell disease, the red cell membrane has increased surface expression of Lutheran antigens and it is hypothesized that 
they could play a role in the adherence of the sickle cells to the endothelial cell wall [8]. The expression of the Lutheran antigens is regulated by the in $(\mathrm{Lu})$ gene which also influences the expression of other associated antigens such as CD44. CD44 is an adhesion molecule and plays a role in the homing of lymphocytes and can influence the immune response [58]. It is therefore very possible that this complex blood group system could play a role in the pathogenesis of HIV. Not much has been published about this blood group. However, a study performed in Botswana showed that the expression of the $\mathrm{Lu}^{\mathrm{b}}$ antigen was significantly more prevalent in patients with HIV, despite the prevalence of this blood group not being any different between the general Botswana population and other African nations [19]. It must, however, be pointed out that this is a single isolated report and before any conclusions can be made, further work is recommended.

CD147, alternatively known as Basigin, belongs to the OK blood group system and is also a member of the immunoglobulin superfamily. It is important in red cell trafficking, cell adhesion, and inflammation, and has been associated with Plasmodium falciparum and HIV [6]. CD147 is a receptor for cyclophilin A, which if integrated into HIV, significantly increases its infectivity. In a study using a cell line transfected with CD147, it was shown that the transfected cells were significantly more sensitive to the virus than controls. After treating the cells with an anti-CD147 antibody, they became resistant to infection. These studies led to the conclusion that cyclophilin A bound to the CD147 molecule could explain the increased sensitivity [59].

Both these blood group systems influence the immune response and inflammation, and therefore it is plausible that they could have an impact on HIV infection. However, the evidence supporting this remains very scarce and therefore inconclusive.

\section{Conclusions}

The main objective of this short review was to provide an update on the association of blood group antigens and the pathogenesis of HIV infection. Although much work has been completed in this area, it is clear that blood groups cannot be studied in isolation, as the function and interaction of red cell surface antigens with other cells and molecules, including pathogens, is multi-faceted.

The red cell membrane is highly complex, and the proteins on its surface interact with many other molecules and extracellular substances. Furthermore, the pathogenesis of infectious disease, and in particular HIV, is intricate and involves not only the binding and fusion of the virus with target cells but also interaction with both the innate and adaptive immune response. These complexities, together with the distribution and genetic diversity of blood group antigen expression, make research in this area challenging.

This mini-review has demonstrated that there is some evidence which suggests that blood group antigens and red blood cells play a role in the susceptibility or protection against HIV infection. However, much of the previous work is superficial and has thus generated more questions than answers. The association of blood group antigens and HIV therefore remains a much neglected area of biological research and further large population studies using high-throughput sequencing to analyze all polymorphic blood groups are required to add further knowledge to this subject.

Author Contributions: G.M.D., substantial contribution to conception, drafting the article and final approval of the version to be published; H.L.H., contributions to conception and final approval of the version to be published; T.E.M., substantial contributions to conception and final approval of the version to be published. All authors have read and agreed to the published version of the manuscript.

Funding: T.EM. is funded by the South African Medical Research Council (SAMRC), with funds from the National Treasury under its Economic Competitiveness and Support Package (MRC-RFA-UFSP-01-2013/VMH Study) and strategic funds from the SAMRC received from the South African National Department of Health.

Conflicts of Interest: There is no conflict of interest to declare with respect to this manuscript. 


\section{References}

1. Global HIV \& AIDS Statistics-2019 Fact Sheet. Geneva, Switzerland: Joint United Nations Programme on HIV/AIDS. 2019. Available online: https://www.unaids.org/en/resources/fact-sheet (accessed on 30 March 2020).

2. Wilen, C.B.; Tilton, J.C.; Doms, R.W. HIV: Cell binding and entry. Cold Spring Harb. Perspect. Med. 2012, 2, a006866. [CrossRef] [PubMed]

3. Horakova, E.; Gasser, O.; Sadallah, S.; Inal, J.M.; Bourgeois, G.; Ziekau, I.; Klimkait, T.; Schifferli, J.A. Complement mediates the binding of HIV-1 to erythrocytes. J. Immunol. 2004, 173, 4236-4241. [CrossRef] [PubMed]

4. Beck, Z.; Brown, B.K.; Wieczorek, L.; Peachman, K.K.; Matyas, G.R.; Polonis, V.R.; Rao, M.; Alving, C.R. Human Erythrocytes Selectively Bind and Enrich Infectious HIV-1 Virions. PLoS ONE 2009, 4, e8297. [CrossRef] [PubMed]

5. Namdar, A.; Dunsmore, G.; Shahbaz, S.; Koleva, P.; Xu, L.; Jovel, J.; Houston, S.; Elahi, S. CD71 ${ }^{+}$Erythroid Cells Exacerbate HIV-1 Susceptibility, Mediate trans-Infection, and Harbor Infective Viral Particles. mBio 2019, 10, e02767-19. [CrossRef] [PubMed]

6. Cooling, L. Blood groups in infection and host susceptibility. Clin. Microbiol. Rev. 2015, 28, 801-867. [CrossRef] [PubMed]

7. Storry, J.R.; Clausen, F.B.; Castilho, L.; Chen, Q.; Daniels, G.; Denomme, G.; Flegel, W.A.; Gassner, C.; de Haas, M.; Hyland, C.; et al. International Society of Blood Transfusion Working party on red Cell Immunogenetics and Blood Group Terminology: Report of the Dubai, Copenhagen and Toronto meetings. Vox Sanguinis 2019, 114, 95-102. [CrossRef]

8. Reid, M.E.; Yahalom, V. Blood groups and their function. Bailliers Best Pract. Res. Clin. Haematol. 2000, 13, 485-509. [CrossRef]

9. Dean, L. The ABO blood group. In Blood Groups and Red Cell Antigens; Bethesda (MD): National Center for Biotechnology Information, National Institutes of Health (NIH): Washington, DC, USA, 2005; Chapter 5; Available online: https:/www.ncbi.nlm.nih.gov/books/NBK2267/.

10. Lund, N.; Olsson, M.L.; Ramkumar, S.; Sakac, D.; Yahalom, V.; Levene, C.; Hellberg, Å.; Ma, X.Z.; Binnington, B.; Jung, D.; et al. The human Pk histo-blood group antigen provides protection against HIV-1 infection. Blood 2009, 113, 4980-4991. [CrossRef]

11. Anstee, J. The relationship between blood groups and disease. Blood 2010, 115, 4635-4643. [CrossRef]

12. Motswaledi, M.S.; Kasvoswe, I.; Oguntibeju, O.O. The role of Red blood cells in enhancing or preventing HIV infection and other diseases. BioMed Res. Int. 2013, 2013. [CrossRef]

13. Fanchini, M.; Bonfanti, C. Evolutionary aspects of ABO blood groups in humans. Clin. Chem. Acta 2015, 444, 66-71. [CrossRef] [PubMed]

14. Benktander, J.; Angstrom, J.; Karlsson, H.; Teymournejad, O.; Linden, S.; Lebens, M.; Teneberg, S. The repertoire of glycosphingolipids recognized by Vibrio Cholera. PLoS ONE 2013, 8, e53999. [CrossRef] [PubMed]

15. Croxen, M.A.; Law, R.J.; Scholz, R.; Keeney, K.M.; Wlodarska, M.; Finlay, B.B. Recent advances in understanding enteric pathogenic Escherichia coli. Clin. Microbiol. Rev. 2013, 26, 822-880. [CrossRef] [PubMed]

16. Jaff, M.S. Relation between ABO blood groups and Helicobacter pylori infection in symptomatic patients. Clin. Exp. Gastroenterol. 2011, 4, 221-226. [CrossRef]

17. Hutson, A.M.; Atmar, R.I.; Marcus, D.M.; Estes, M.K. Norwalk virus infection and disease are associated with the ABO histo-blood group type. J. Infect. Dis. 2002, 185, 1335-1337. [CrossRef]

18. Barbé, L.; Le Moullac-Vaidye, B.; Echasserieau, K.; Bernardeau, K.; Carton, T.; Bovin, N.; Nordgren, J.; Svensson, L.; Ruvoën-Clouet, N.; Le Pendu, J. Histo-blood group antigen-binding specificities of human rotaviruses are associated with gastroenteritis but not with in vitro infection. Sci. Rep. 2018, 8, 1-4. [CrossRef]

19. Motswaledi, M.S.; Kasvosve, I.; Oguntibeju, O.O. Blood group antigens C, Lub and P1 may have a role in HIV infection in Africans. PLoS ONE 2016, 11, e149883. [CrossRef]

20. Rowe, J.A.; Opi, D.H.; Williams, T.N. Blood groups and malaria: Fresh insights into pathogenesis and identification of targets for intervention. Curr. Opin. Hematol. 2009, 16, 480-487. [CrossRef] 
21. Fanales-Belasio, E.; Raimondo, M.; Suligoi, B.; Butto, S. HIV virology and pathogenetic mechanisms of infection: A brief overview. Ann. Ist. Super. Sanità 2010, 46, 5-14. [CrossRef]

22. Seitz, R. Human Immunodeficiency Virus (HIV) (For German Advisory Committee Blood). Transfus. Med. Hemother. 2016, 43, 203-222. [CrossRef]

23. Hillerman, M.R. Comparative biology and pathogenesis of AIDS and Hepatitis B Viruses: Related but different. AIDS Res. Hum. Retroviruses 1994, 10, 1409-1419. [CrossRef] [PubMed]

24. Naif, H.M. Pathogenesis of HIV Infection. Infect. Dis. Rep. 2013, 6, e6. [CrossRef] [PubMed]

25. Kurapati, K.R.; Samikkannu, T.; Atluri, V.S.; Nair, M.P. Cell cycle checkpoints and pathogenesis of HIV-1 infection: A brief overview. J. Basic Clin. Physiol. Pharmacol. 2014, 26, 1-11. [CrossRef] [PubMed]

26. Yakovian, O.; Schwartzer, R.; Sajman, J.; Neve-Oz, Y.; Razwag, Y.; Herrmann, A.; Sherman, E. Gp41 dynamically interacts with the TCR in the immune synapse and promotes early T-cell activation. Sci. Rep. 2018, 8, 9747. [CrossRef]

27. Neill, S.J.D.; McKnight, A.; Gustafsson, K.; Weiss, R.A. HIV-1 incorporates ABO histo-blood group antigens that sensitize virions to complement-mediated inactivation. Blood 2005, 105, 4693-4699. [CrossRef]

28. Canizalez-Román, A.; Campos-Romero, A.; Castro-Sánchez, J.A.; López-Martínez, M.A.; Andrade-Muñoz, F.J.; Cruz-Zamudio, C.K.; Ortíz-Espinoza, T.G.; León-Sicairos, N.; Llanos, G.; Alma, M.; et al. Blood Groups Distribution and Gene Diversity of the $\mathrm{ABO}$ and $\mathrm{Rh}(\mathrm{D})$ Loci in the Mexican Population. BioMed Res. Int. 2018, 2018. [CrossRef]

29. Farhud, D.D.; Yeganeh, M.Z. A brief history of human blood groups. Iran. J. Public Health 2013, 42, 1-6. [PubMed]

30. Turcot-Dubois, A.L.; Le Moullac-Vaidye, B.; Despiau, S.; Roubinet, F.; Bovin, N.; Le Pendu, J.; Blancher, A. Long-term evolution of the CAZY glycosyltransferase $6(\mathrm{ABO})$ gene family from fishes to mammals-A birth-and-death evolution model. Glycobiology 2007, 17, 516-528. [CrossRef]

31. Rowe, J.A.; Handel, I.G.; Thera, M.A.; Deans, A.M.; Lyke, K.E.; Koné, A.; Diallo, D.A.; Raza, A.; Kai, O.; Marsh, K.; et al. Blood group O protects against severe Plasmodium falciparum malaria through the mechanism of reduced rosetting. Proc. Natl. Acad. Sci. USA 2007, 104, 17471-17476. [CrossRef]

32. Rowe, J.A.; Claessens, A.; Corrigan, R.A.; Arman, M. Adhesion of Plasmodium falciparum-infected erythrocytes to human cells: Molecular mechanisms and therapeutic implications. Exp. Rev. Mol. Med. 2009, 11, e16. [CrossRef] [PubMed]

33. Koike, C.; Uddin, M.; Wildman, D.E.; Gray, E.A.; Trucco, M.; Starzl, T.E.; Goodman, M. Functionally important glycosyltransferase gain and loss during catarrhine primate emergence. Proc. Natl. Acad. Sci. USA 2007, 104, 559-564. [CrossRef] [PubMed]

34. Karlsson Hedestam, G.B.; Fouchier, R.A.; Phogat, S.; Burton, D.R.; Sodroski, J.; Wyatt, R.T. The challenges of eliciting neutralizing antibodies to HIV-1 and to influenza virus. Nat. Rev. Microbiol. 2008, 6, 143-155. [CrossRef] [PubMed]

35. Weir, D.M.; Stewart, J. Immunohaematology. In Immunology, Revised 8th ed.; Stewart, J., Ed.; Churchill Livingstone: New York, NY, USA, 1997; pp. 232-241.

36. Sayal, S.K.; Das, A.L.; Nema, S.K. Study of blood groups in HIV seropositive patients. Indian J. Dermatol. Venereol. Leprol. 1996, 62, 295-297. [PubMed]

37. Davison, G.M.; Hendrickse, H.L.; Matsha, T.E. The relationship between immunogenic red blood cell antigens and HIV. J. Transci. 2018, 57, 58-62. [CrossRef]

38. Abdulazeez, A.A.; Alo, E.B.; Rebecca, S.N. Carriage rate of Human Immunodeficiency Virus (HIV infection among $\mathrm{ABO}$ and Rhesus blood groups in Adamawa state, Nigeria. Biomed. Res. 2008, 19, 41-44.

39. Onsten, T.G.; Callegari-Jacques, S.M.; Goldani, L.Z. The Higher Frequency of Blood Group B in a Brazilian Population with HIV Infection. Open Aids J. 2013, 7, 47-50. [CrossRef]

40. Siransky, L.K.; Nanga, Z.Y.; Zaba, F.S.; Tufa, N.Y.; Dasse, S.R. ABO/Rh Blood groups and risk of HIV infection and Hepatitis B among blood donors of Abidjan, Cote D'Ivoire. Eur. J. Microbiol. Immunol. 2015, 5, 205-209. [CrossRef]

41. Nkenfou, C.N.; Nkenfou, C.N.; Tiedeu, B.A.; Mbanya, D. ABO-Rhesus Blood Groups and susceptibility to HIV infection. J. Pharm. Chem. Biol. Sci. 2015, 3, 324-328.

42. Bamisaye, E.; Adepeju, A.; Akanni, E.; Akinbo, D.; Omisore, A. Association between Blood Group Antigens, CD4 Cell Count and Haemoglobin Electrophoretic Pattern in HIV Infection. Int. J. Life Sci. Sci. Res. 2017, 3, 1300-1304. [CrossRef] 
43. Ferrer-Admetlla, A.; Sikora, M.; Laayouni, H.; Esteve, A.; Roubinet, F.; Blancher, A.; Calafell, F. A Natural History of FUT2 polymorphism in Humans. Mol. Biol. Evol. 2009, 26, 1993-2003. [CrossRef]

44. Huang, P.; Farkas, T.; Marionneau, S.; Zhong, W.; Ruvoën-Clouet, N.; Morrow, A.L.; Altaye, M.; Pickering, L.K.; Newburg LePendu, J.; Jiang, X. Noroviruses Bind to Human ABO, Lewis, and Secretor Histo-Blood Group Antigens: Identification of 4 Distinct Strain-Specific Patterns. J. Infect. Dis. 2003, 188, 19-31. [CrossRef] [PubMed]

45. Ali, S.; Niang, M.A.F.; N'doye, I.; Critchlow, C.W.; Hawes, S.E.; Hill, A.V.S.; Kiviat, N.B. Secretor Polymorphism and Human Immunodeficiency Virus Infection in Senegalese Women. J. Infect. Dis. 2000, 181, 737-739. [CrossRef]

46. Nordgren, J.; Nitiema, L.W.; Ouermi, D.; Simpore, J.; Svensson, L. Host Genetic Factors Affect Susceptibility to Norovirus Infections in Burkina Faso. PLoS ONE 2013, 8, e69557. [CrossRef] [PubMed]

47. Chanzu, N.M.; Mwanda, W.; Oyugi, J.; Anzala, O. Mucosal Blood Group Antigen Expression Profiles and HIV Infections: A Study among Female Sex Workers in Kenya. PLoS ONE 2015, 10, e0133049. [CrossRef] [PubMed]

48. Blackwell, C.C.; James, V.S.; Davidson, S.; Wyld, R.; Brettle, R.P.; Robertson, R.J.; Weir, D.M. Secretor status and heterosexual transmission of HIV. BMJ 1991, 303, 825-826. [CrossRef]

49. Horuk, R. The Duffy antigen receptor for chemokines DARC/ACKR1. Front. Immunol. 2015, 6, 279. [CrossRef]

50. Schnabel, R.B.; Baumert, J.; Barbalic, M.; Dupuis, J.; Ellinor, P.T.; Durda, P.; Dehghan, A.; Bis, J.C.; Illig, T.; Morrison, A.C.; et al. Duffy antigen receptor for chemokines (Darc) polymorphism regulates circulating concentrations of monocyte chemoattractant protein-1 and other inflammatory mediators. Blood 2010, 115, 5289-5299. [CrossRef]

51. Walton, R.T.; Rowland-Jones, S.L. HIV and Chemokine binding to red cells-DARC matters. Cell Host Microb. 2008, 4, 3-5. [CrossRef]

52. Weiss, R. Influence of Duffy antigen receptor for chemokines on HIV infection. Retrovirology 2013, $10, \mathrm{O} 31$. [CrossRef]

53. He, W.; Neil, S.; Kulkarni, H.; Wright, E.; Agan, B.K.; Marconi, V.C.; Dolan, M.J.; Weiss, R.A.; Ahuja, S.K. Duffy Antigen Receptor for Chemokines Mediates trans-Infection of HIV- 1 from Red Blood Cells to Target Cells and Affects HIV-AIDS Susceptibility. Cell Host Microb. J. 2008, 4, 52-62. [CrossRef]

54. Kulkarni, H.; Marconi, V.C.; He, W.; Landrum, M.L.; Okulicz, J.F.; Delmar, J.; Ahuja, S.K. The Duffy-null state is associated with a survival advantage in leukopenic HIV-infected persons of African ancestry. Blood 2009, 114, 2783-2792. [CrossRef] [PubMed]

55. Ramsuran, V.; Kulkarni, H.; He, W.; Mlisana, K.; Wright, E.J.; Werner, L.; Castiblanco, J.; Dhanda, R.; Le, T.; Dolan, M.J.; et al. Duffy-Null-Associated Low neutrophil Counts Influence HIV-1 Susceptibility in High-Risk South African Black Women. Clin. Infect. Dis. 2011, 52, 1248-1256. [CrossRef] [PubMed]

56. Winkler, C.A.; Ping An Johnson, R.; Nelson, G.W.; Kirk, G. Expression of Duffy Antigen Receptor for Chemokines (DARC) Has No Effect on HIV-1 Acquisition or Progression to AIDS in African Americans. Cell Host Microb. 2009, 5, 411-413. [CrossRef] [PubMed]

57. Nicole Lund, N.; Branch, D.; Sakac, D.; Lingwood, C.; Siatskas, C.; Robinson, C.; Brady, R.; Medin, J. Lack of susceptibility of cells from patients with Fabry disease to productive infection with R5 human immunodeficiency virus. AIDS 2005, 19, 1543-1546. [CrossRef] [PubMed]

58. Telen, M.J. Lutheran antigens, CD44-related antigens, and Lutheran regulatory genes. Transfus Clin. Biol. 1995, 2, 291-301. [CrossRef]

59. Pushkarsky, T.; Zybarth, G.; Dubrovsky, L.; Yurchenko, V.; Tang, H.; Guo, H.; Bukrinsky, M. CD147 facilitates HIV-1 infection by interacting with virus-associated cyclophilin A. Proc. Natl. Acad. Sci. USA 2001, 98, 6360-6365. [CrossRef]

(C) 2020 by the authors. Licensee MDPI, Basel, Switzerland. This article is an open access article distributed under the terms and conditions of the Creative Commons Attribution (CC BY) license (http://creativecommons.org/licenses/by/4.0/). 